\title{
Usnic Acid. VII.1) The Pyrolysis of Methyldihydrousnic Acid
}

\author{
Kōtaro Takahashi and Masako Takani \\ Faculty of Pharmaceutical Sciences, University of Kanazawa ${ }^{2)}$
}

(Received February 20, 1970)

\begin{abstract}
1) The structures of two pyrolysis products of methyldihydrousnic acid (I) were established to be II and III, respectively.

2) The mechanism of the formation of II and III from I were discussed.

3) The mass spectra of $\mathrm{V}$ and isoanhydromethyldihydrousnic acid monoacetate, and $\mathrm{X}$ and anhydromethyldihydrousnic acid monoacetate were studied.
\end{abstract}

The structural formula of usnic acid ${ }^{3)}$ was established, and recently the structure of isousnic acid was elucidated by Shibata and Taguchi. ${ }^{4)}$ Although some explanations ${ }^{3}$ have been presented for the remarkable difference between usnic- and dihydrousnic-acid in the degradation reactions, any unequivocal experimental proof has not been provided as yet. In a previous paper, ${ }^{5}$ ) the author reported that 3-methyl-2,6-dihydroxyacetophenone, a resorcinol type of compound, but not 6-hydroxy-3,5-dimethyl-7-acetylcoumaranone-2 ${ }^{3)}$ was obtained from methyldihydrousnic acid (I) by the potassium permanganate oxidation, followed by the vacuum distillation, to suggest that it was derived from the ring $B$ of $I$. The present paper deals with the pyrolysis products of I. On heating at $220-240^{\circ}$ for $30 \mathrm{~min}$ under ordinary pressure, I liberated acetic acid and acetylacetone. The residue afforded on subsequent distillation at $220-240^{\circ}$ under diminished pressure $(1 \mathrm{mmHg})$ faint yellow

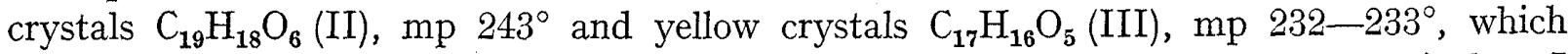
might have been resulted from $\mathrm{I}$ by the loss of $\mathrm{H}_{2} \mathrm{O}$, and $\mathrm{H}_{2} \mathrm{O}$ and $\mathrm{COCH}_{2}$, respectively. I gave also II and III by the distillation with $\mathrm{CaCl}_{2}$, but no coumaranone type of compound such as 6-hydroxy-3,5-dimethyl-7-acetylcoumaranone-2 was obtained. II gave violet brown coloration with $\mathrm{FeCl}_{3}$ and afforded bisoxime monoanhydride $\mathrm{C}_{19} \mathrm{H}_{18} \mathrm{O}_{5} \mathrm{~N}_{2}$ (IV), mp 287 , by the action of hydroxylamine hydrochloride, suggesting the presence of a carbonyl group located at the ortho position of an enolic $\mathrm{OH}$ group. By the acetylation with acetic anhydride and conc. $\mathrm{H}_{2} \mathrm{SO}_{4}$ or with acetic anhydride and sodium acetate, $\mathrm{II}$ gave monoacetate $\mathrm{C}_{21} \mathrm{H}_{20} \mathrm{O}_{7}(\mathrm{~V})$, mp $128^{\circ}$, which gave by the ozonolysis, $\mathrm{C}_{12} \mathrm{H}_{12} \mathrm{O}_{6}(\mathrm{VI}), \mathrm{mp} 170-172^{\circ}$. VI gave methyl ester $\mathrm{C}_{13} \mathrm{H}_{14} \mathrm{O}_{6}$ (VII), mp 123-125 , with diazomethane, which was deacetylated to $\mathrm{C}_{11} \mathrm{H}_{12} \mathrm{O}_{5}$ (VIII), mp 102-103\%. VI gave 3-methyl-2,6-dihydroxyacetophenone, $\left.{ }^{5}\right) \mathrm{C}_{9} \mathrm{H}_{10} \mathrm{O}_{3}$ (IX), mp $134-136^{\circ}$, by the hydrolysis with $10 \%$ ethanolic $\mathrm{KOH}$, followed by decarboxylation. Monoacetate $(V)$ was deacetylated to II with conc. $\mathrm{H}_{2} \mathrm{SO}_{4}$. III gave a red coloration with $\mathrm{FeCl}_{3}$ and afforded diacetate $\mathrm{C}_{21} \mathrm{H}_{20} \mathrm{O}_{7}(\mathrm{X}), \mathrm{mp} 165-166^{\circ}$, with acetic anhydride and conc. $\mathrm{H}_{2} \mathrm{SO}_{4}$ or with acetic anhydride and sodium acetate. $\mathrm{X}$ gave $\mathrm{VI}$ by the ozonolysis and monoacetate $\mathrm{C}_{19} \mathrm{H}_{18} \mathrm{O}_{6}(\mathrm{XI}), \mathrm{mp} 218-219^{\circ}$, by the ethanolysis. $\mathrm{X}$ was deacetylated to III with conc. $\mathrm{H}_{2} \mathrm{SO}_{4}$. These chemical evidences mentioned above suggest that the aromatisation is effected in the course of the pyrolysis, not in the course of the acetylation by the Dienone-Phenol rearrangement, $\left.{ }^{6}\right)$ and that the pyrolysis products II and III possess a 3-methyl-2,6-dihydroxyacetophenone structure in the molecules (Chart 1).

1) Part VI: K. Takahashi and S. Miyashita, Chem. Pharm. Bull. (Tokyo), 16, 988 (1968).

2) Location: Takaramachi, Kanazawa.

3) Y. Asahina and S. Shibata "The Chemistry of Lichen Substances", Japan Society for the Promotion of Science, Tokyo, Japan, 1954, p. 190.

4) S. Shibata and H. Taguchi, Tetrahedron Letters, 1967, 4867.

5) K. Takahashi and S. Miyashita, Chem. Pharm. Bull. (Tokyo), 10, 603 (1962).

6) K. Takahashi and S. Miyashita, Chem. Pharm. Bull. (Tokyo), 11, 209 (1963). 


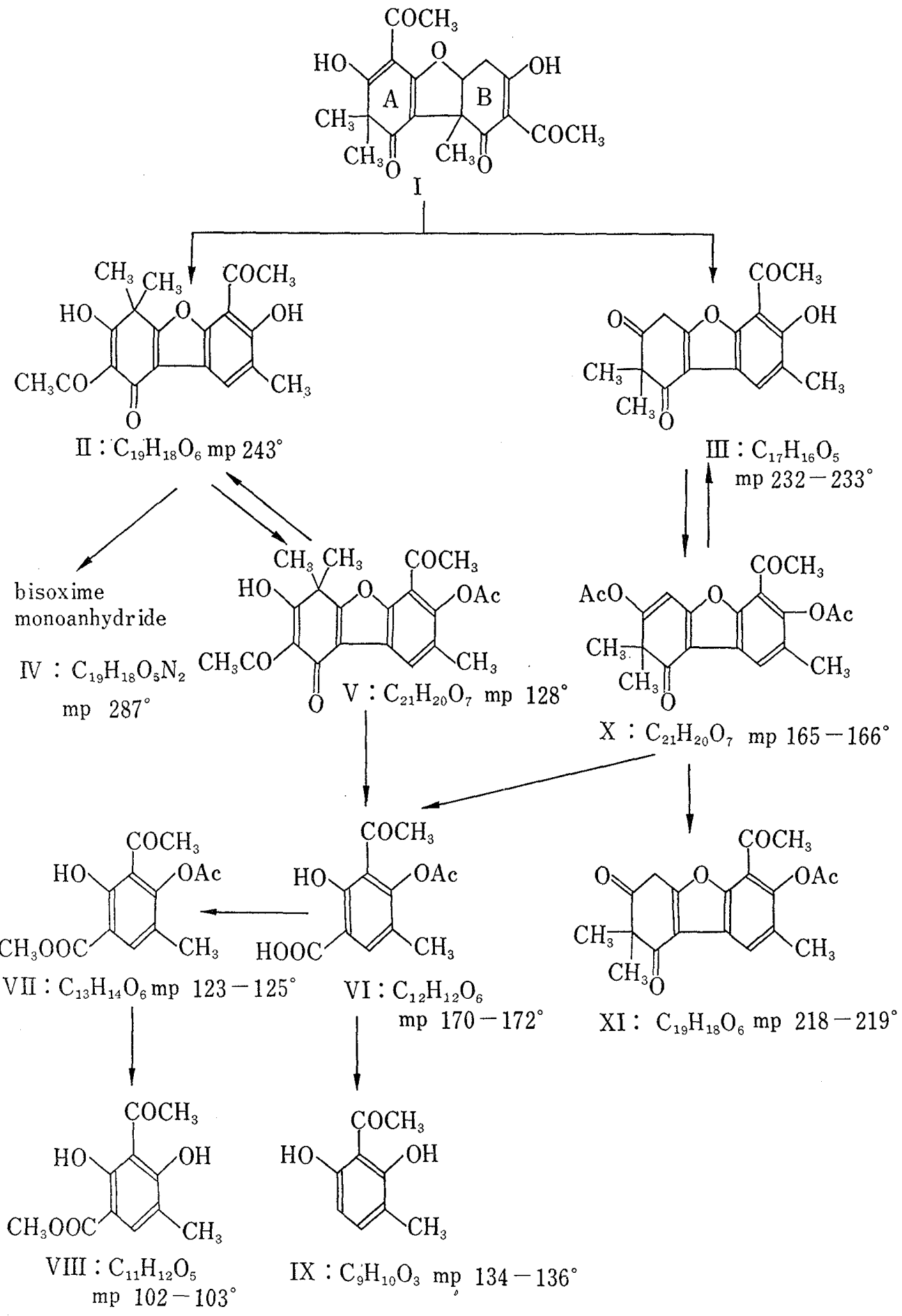

Chart 1

The structure of $\mathrm{C}_{12} \mathrm{H}_{12} \mathrm{O}_{6}$ (VI) was elucidated as follows: VI gave violet coloration with $\mathrm{FeCl}_{3}$ and exhibited infrared (IR) bands $\left(\mathrm{cm}^{-1}\right)$ at 1770 (acetate), 1655, 1650 (chelated $\mathrm{COOH}$ and aryl-COCH$\left.{ }_{3}\right)$. VII showed IR bands $\left(\mathrm{cm}^{-1}\right)$ at 1755 (acetate), 1690 (chelated $\left.\mathrm{COOCH}_{3}\right)$ and $1675\left(\operatorname{aryl}-\mathrm{COCH}_{3}\right)$. VI, VII and VIII were negative to the Gibbs reaction indicating that the para positions to $\mathrm{OH}$ groups are substituted. Therefore, it is reasonable to assume that VI, from which IX was derived, is methylresacetophenone carboxylic acid monoacetate and VII is methyl methylresacetophenone carboxylate monoacetate. There are three possible structures $\mathrm{a}, \mathrm{b}$ and $\mathrm{c}$ for VII. 
<smiles>COc1cc(C)c(OC(C)=O)c(O)c1C(C)=O</smiles>

a<smiles></smiles><smiles></smiles>

Now, by the comparison of $\tau$-values of aryl- $\mathrm{CH}_{3}$ (7.76) and aryl- $\mathrm{H}(3.75)$ of $\mathrm{A}^{6)}$ with those of aryl- $\mathrm{CH}_{3}(7.54)$ and aryl- $\mathrm{H}(3.75)$ of $\left.\mathrm{B},{ }^{6}\right)$ the following conclusion could be deduced that the $\mathrm{COOCH}_{3}$ group causes the diamagnetic shift of the methyl group at ortho position (7.76 to 7.54), but does not effect the chemical shift of the aryl-H at meta position. VII and IX show the aryl- $\mathrm{CH}_{3}$ signals at nearly equal $\tau$-values (7.89 and 7.82), but VII shows the signal of the aryl-H at lower field (2.24) than those of the aryl-H of IX to suggest that VII has a $\mathrm{COOCH}_{3}$ group at meta position to the $\mathrm{CH}_{3}$ group and a proton at ortho position to the $\mathrm{COOCH}_{3}$ group (Table I). These nuclear magnetic resonance (NMR) and IR spectral data indicate that VII would be a.

TABLE I. The NMR Data ( $\tau$-Value in $\mathrm{CDCl}_{3}, 60 \mathrm{Mc}$ )

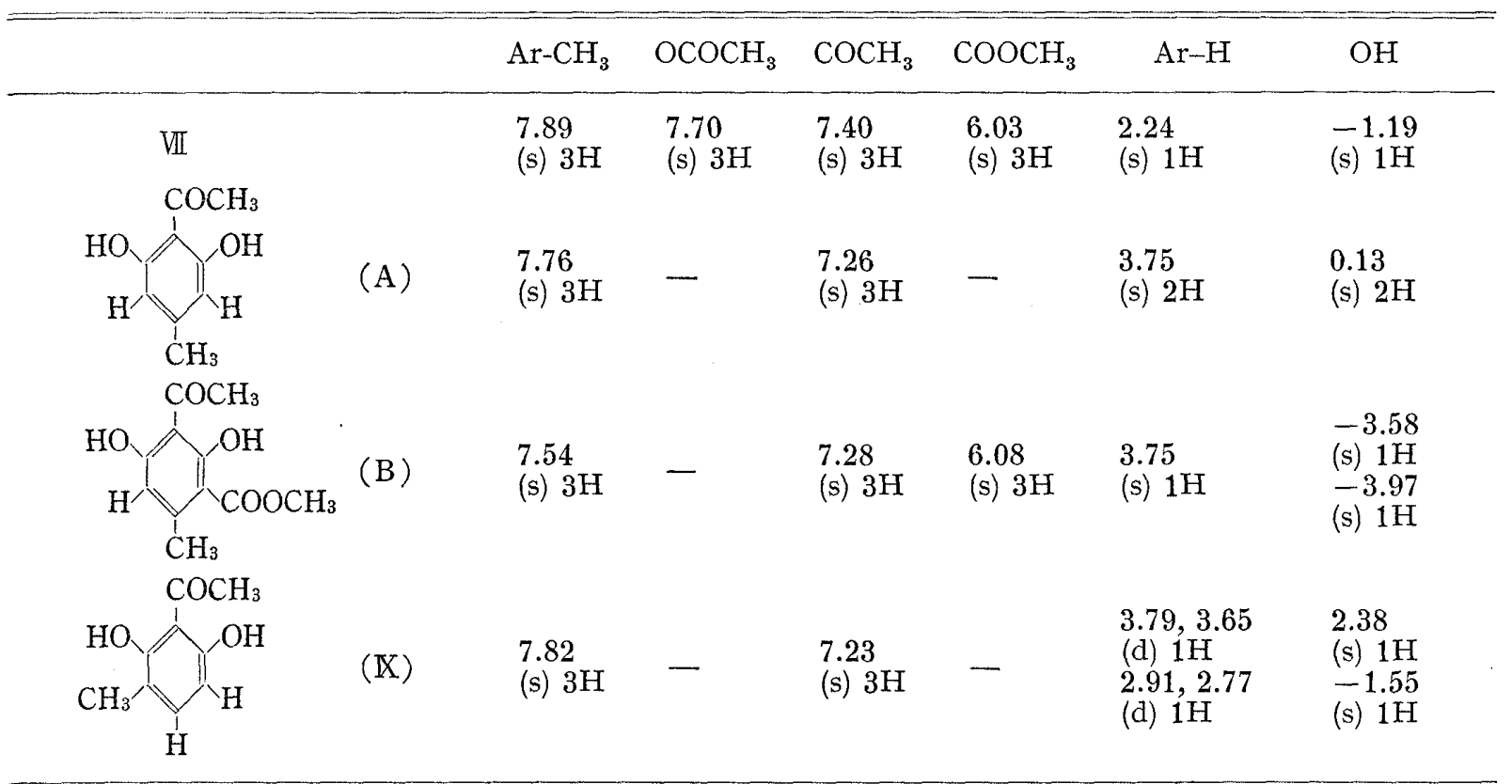

abbreviation: s; singlet, d; doublet

The ultraviolet (UV) spectrum of II shows absorption maxima $(\mathrm{m} \mu, \log \varepsilon)$ at $237.2(4.24)$, 274.4 (4.03), 284.0 (4.00, sh) and 328 (3.63), and the IR bands $\left(\mathrm{cm}^{-1}\right)$ at $1660\left(\alpha \beta-\alpha^{\prime} \beta^{\prime}\right.$-unsatd. $\mathrm{C}=\mathrm{O}$ ), 1648 and 1635 (two chelated $\mathrm{C}=\mathrm{O}$ ), 1530-1550 (broad, triketone) and 1125, $1018(-\mathrm{C}-$ $\mathrm{O}-\mathrm{C}-$ ). These spectral data closely resemble those of isoanhydromethyldihydrousnic acid,7) with UV maxima ${ }^{8)}$ at $238(4.54), 270(4.27, \mathrm{sh}), 283(4.32)$ and $330(3.95)$ and the IR bands ${ }^{8)}$ at $1657\left(\alpha \beta-\alpha^{\prime} \beta^{\prime}\right.$-unsatd. $\mathrm{C}=\mathrm{O}$ ), 1650 and 1640 (two chelated $\mathrm{C}=\mathrm{O}$ ) and 1530-1550 (broad, triketone) and 1182, $1070(-\mathrm{C}-\mathrm{O}-\mathrm{C}-$ ). The NMR of II could be assigned as shown in Table II, with reference to those of isoanhydromethyldihydrousnic acid and anhydromethyldihydro-

7) K. Takahashi, S. Miyashita and Y. Ueda, Chem. Pharm. Bull. (Tokyo), 11, 473 (1963).

8) The UV and IR spectra were newly measured by Hitachi EPS-2U recording spectrophotometer and Nippon Bunko D.S. 402G IR spectrometer, respectively. 
usnic acid. ${ }^{6}$ These spectral data suggest that the chromophores of both compounds II and isoanhydromethyldihydrousnic acid are almost same and almost equally situated in the molecules, except the aryl- $\mathrm{CH}_{3}$ groups.

TABLE II. The NMR Data ( $\tau$-Value and $\delta$-Value, $60 \mathrm{Mc})$

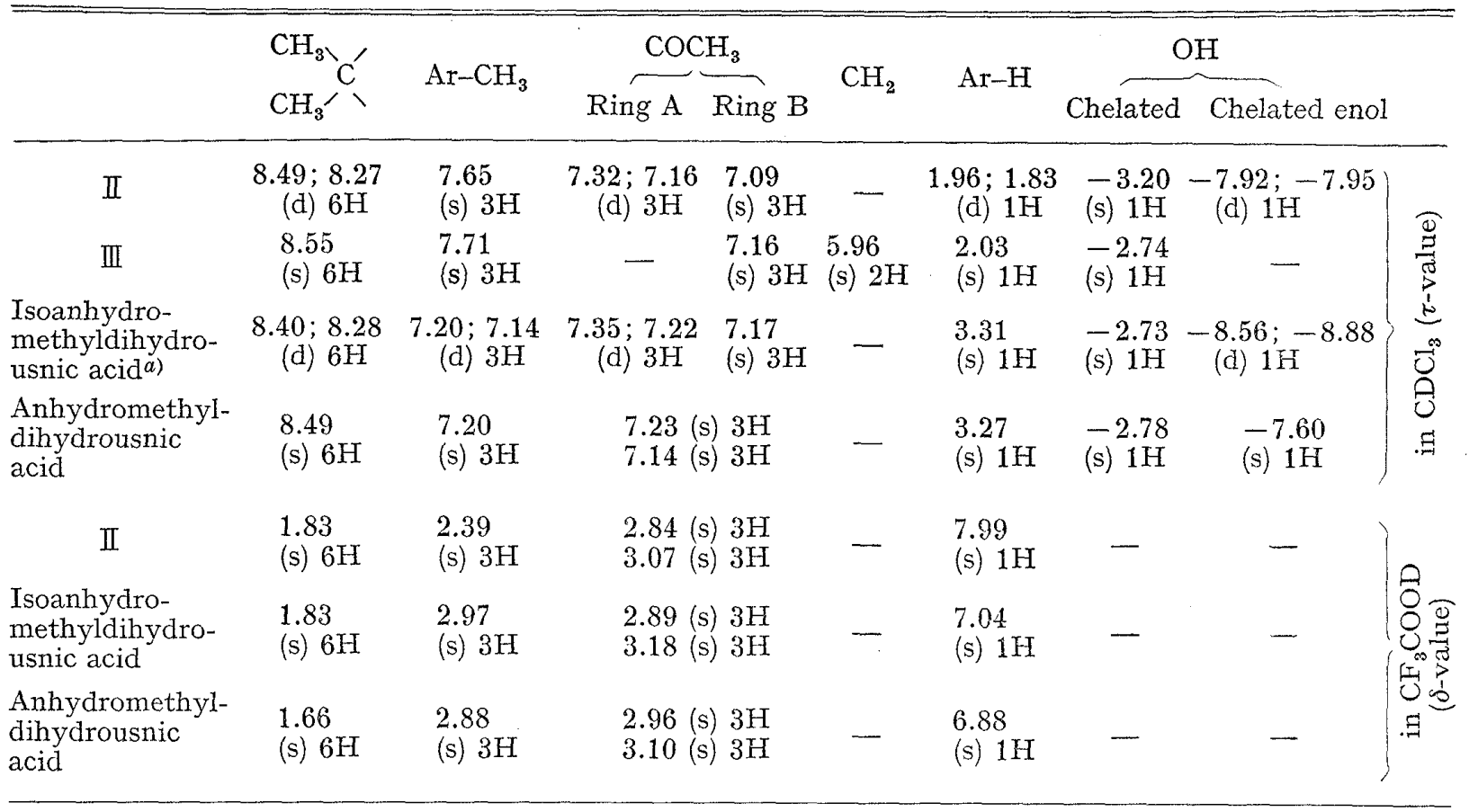

a) The NMR spectrum was newly measured by JNM-C-60-H high resolution NMR instrument and some of assignments ?) of signals were revised.

II exhibits the NMR signals of gem-dimethyl, $\mathrm{COCH}_{3}$ group of the ring $\mathrm{A}$, aryl-H and chelated enol $\mathrm{OH}$ group as doublets in $\mathrm{CDCl}_{3}$, but those of the gem-dimethyl, the $\mathrm{COCH}_{3}$ group of the ring $\mathrm{A}$ and the aryl- $\mathrm{H}$ as singlets in $\mathrm{CF}_{3} \mathrm{COOD}$ and $\mathrm{D}_{2} \mathrm{O}$ solution, respectively, thus suggesting that II is an isotype of compound and exists in two types of enol form and is equilibrium between<smiles>CC(=O)C1=C(C(C)=O)c2c(oc(=O)c(C(C)=O)c2O)C(C)(C)C1=O</smiles>
and<smiles></smiles>

as isoanhydromethyldihydrousnic acid.

Acetate (V) of II exhibits NMR signals as shown in Table III. V exhibits the signal of a chelated enol $\mathrm{OH}$ group, but does not exhibit a signal of a chelated $\mathrm{OH}$ group, indicating that the aryl-OH group of II was acetylated to give V. The splitting of the signals of the gemdimethyl, the $\mathrm{COCH}_{3}$ group of the ring $\mathrm{A}$, the aryl- $\mathrm{H}$ and the chelated enol $\mathrm{OH}$ group indicates that $\mathrm{V}$ is an isotype of compound and exists in two types of enol form as II.

The IR bands $\left(\mathrm{cm}^{-1}\right)$ of $\mathrm{V}, 1770$ (acetate), 1687 (aryl- $\left.\mathrm{COCH}_{3}\right), 1662\left(\alpha \beta\right.$ - $\alpha^{\prime} \beta^{\prime}$-unsatd. ring $\mathrm{C}=\mathrm{O}$ ), 1620 (chelated $\mathrm{C}=\mathrm{O}), 1515-1554$ (broad, triketone) and 1125, 1018 (-C-O-C-) resemble those of isoanhydromethyldihydrousnic acid monoacetate, ${ }^{7)} 1767$ (acetate), 1688 $\left(\right.$ aryl- $\mathrm{COCH}_{3}$ ), $1658\left(\alpha \beta-\alpha^{\prime} \beta^{\prime}\right.$-unsatd. ring $\mathrm{C}=\mathrm{O}$ ), 1620 (chelated $\mathrm{C}=\mathrm{O}$ ), 1525-1545 (broad, triketone) and 1145, 1055 (-C-O-C-). The UV maxima of $\mathrm{V}(\mathrm{m} \mu, \log \varepsilon), 231.3(4.44), 258.2$ $(4.22, \mathrm{sh})$ and $302.8(4.10)$ also resemble those of isoanhydromethyldihydrousnic acid mono- 
TABLE III. The NMR Data ( $\tau$-Value in $\left.\mathrm{CDCl}_{3}, 60 \mathrm{Mc}\right)$

\begin{tabular}{|c|c|c|c|c|c|c|c|}
\hline & \multirow{2}{*}{$\begin{array}{l}\mathrm{CH}_{3 \backslash,} \mathrm{C}^{\prime} \\
\mathrm{CH}_{3}^{\prime} \backslash\end{array}$} & \multirow{2}{*}{$\mathrm{Ar}-\mathrm{CH}_{3}$} & \multirow{2}{*}{$\mathrm{OCOCH}_{3}$} & \multicolumn{2}{|c|}{$\mathrm{COCH}_{3}$} & \multirow{2}{*}{$\mathrm{Ar}-\mathrm{H}$} & \multirow{2}{*}{$\begin{array}{c}\text { Chelated enol } \\
\text { OH }\end{array}$} \\
\hline & & & & Ring A & Ring B & & \\
\hline $\mathrm{V}$ & $\begin{array}{l}8.42 ; 8.31 \\
\text { (d) } 6 \mathrm{H}\end{array}$ & $\begin{array}{l}7.69 \\
\text { (s) } 3 \mathrm{H}\end{array}$ & $\begin{array}{l}7.62 \\
\text { (s) } 3 \mathrm{H}\end{array}$ & $\begin{array}{l}7.33 ; 7.17 \\
\text { (d) } 3 \mathrm{H}\end{array}$ & $\begin{array}{l}7.23 \\
\text { (s) } 3 \mathrm{HI}\end{array}$ & $\begin{array}{l}1.96 ; 1.82 \\
\text { (d) } 1 \mathrm{H}\end{array}$ & $\begin{array}{c}-8.41 ;-8.43 \\
\text { (d) } 1 \mathrm{H}\end{array}$ \\
\hline $\begin{array}{l}\text { Isoanhydro- } \\
\text { methyldihydro- } \\
\text { usnic acid } \\
\text { monoacetate }\end{array}$ & $\begin{array}{l}8.41 ; 8.29 \\
\quad \text { (d) } 6 \mathrm{H}\end{array}$ & $\begin{array}{l}7.18 ; 7.11 \\
\text { (d) } 3 \mathrm{H}\end{array}$ & $\begin{array}{l}7.69 \\
\text { (s) } 3 \mathrm{H}\end{array}$ & $\begin{array}{l}7.38 ; 7.25 \\
\text { (d) } 3 \mathrm{H}\end{array}$ & $\begin{array}{l}7.29 \\
\text { (s) } 3 \mathrm{H}\end{array}$ & $\begin{array}{l}3.20 \\
\text { (s) } 1 \mathrm{H}\end{array}$ & $\begin{array}{c}-8.47 ;-8.73 \\
\text { (d) } 1 \mathrm{H}\end{array}$ \\
\hline $\begin{array}{l}\text { Anhydromethyl- } \\
\text { dihydrousnic acid } \\
\text { monoacetate }\end{array}$ & $\begin{array}{l}8.50 \\
\text { (s) } 6 \mathrm{H}\end{array}$ & $\begin{array}{l}7.16 \\
\text { (s) } 3 \mathrm{H}\end{array}$ & $\begin{array}{l}7.69 \\
\text { (s) } 3 \mathrm{H}\end{array}$ & $\begin{array}{l}7.24,(\mathrm{~s}) \\
7.33,(\mathrm{~s})\end{array}$ & $\begin{array}{l}3 \mathrm{H} \\
3 \mathrm{H}\end{array}$ & $\begin{array}{l}3.18 \\
\text { (s) } 1 \mathrm{H}\end{array}$ & $\begin{array}{l}-7.90 \\
\text { (s) } 1 \mathrm{H}\end{array}$ \\
\hline
\end{tabular}

a) The NMR spectrum was newly measured by JNM-C-60-H high resolution NMR instrument and some of assignments ${ }^{6}$ ) of signals were revised.

acetate, $234.7(4.45), 260.7(4.21, \mathrm{sh})$ and $304.2(4.01)$. These chemical and spectral data indicate that II, V, VI, VII and VIII could be formulated as shown in Chart 1.

$\mathrm{C}_{17} \mathrm{H}_{16} \mathrm{O}_{5}$ (III) exhibits the IR bands $\left(\mathrm{cm}^{-1}\right)$ at 1725 (six-membered ring $\mathrm{C}=\mathrm{O}$ ), 1680 $(\alpha \beta$-unsatd. six-membered ring $\mathrm{C}=\mathrm{O}), 1635$ (chelated aryl- $\left.\mathrm{COCH}_{3}\right)$ and the UV maxima $(\mathrm{m} \mu$, $\log \varepsilon)$ at $266.2(4.38), 282.0(4.23, \mathrm{sh})$ and $302.0(3.81, \mathrm{sh})$. The NMR signals are shown in Table II. The NMR signals ( $\tau$-value) at 8.55 (s, $6 \mathrm{H}$, a gem-dimethyl) and $5.96(\mathrm{~s}, 2 \mathrm{H}$, a methylene group which could be considered to be produced by the hydrolytic fission of $\mathrm{COCH}_{3}$ group of the ring $\mathrm{A}$ of $\mathrm{I})$ and $2.03(\mathrm{~s}, 1 \mathrm{H}$, aryl-H), and the IR bands indicate that III exists in a diketoform as 2,2,5,5-tetramethylhexane-1,3-dione. ${ }^{9)}$ Diacetate (X) of III, which gave VI by the ozonolysis, exhibits the IR bands $\left(\mathrm{cm}^{-1}\right)$ at 1776 and 1765 (two acetates), 1693 (aryl$\left.\mathrm{COCH}_{3}\right), 1660(\alpha \beta \gamma \delta$-unsatd. ring $\mathrm{C}=\mathrm{O})$ and $1175,1045(-\mathrm{C}-\mathrm{O}-\mathrm{C}-)$ and the NMR signals $(\tau$ -

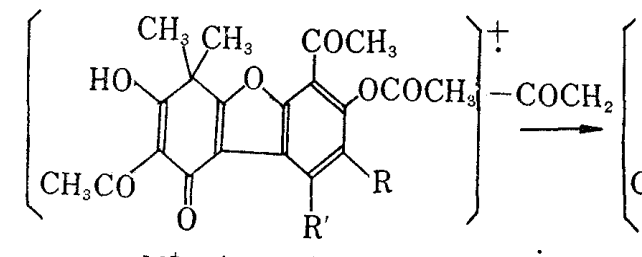

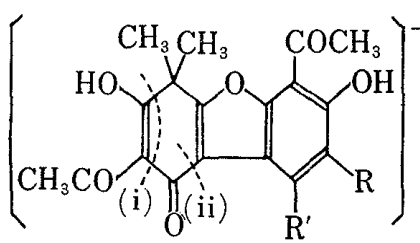

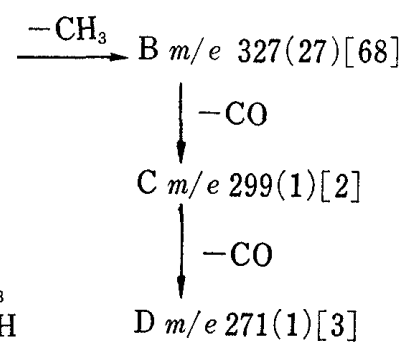

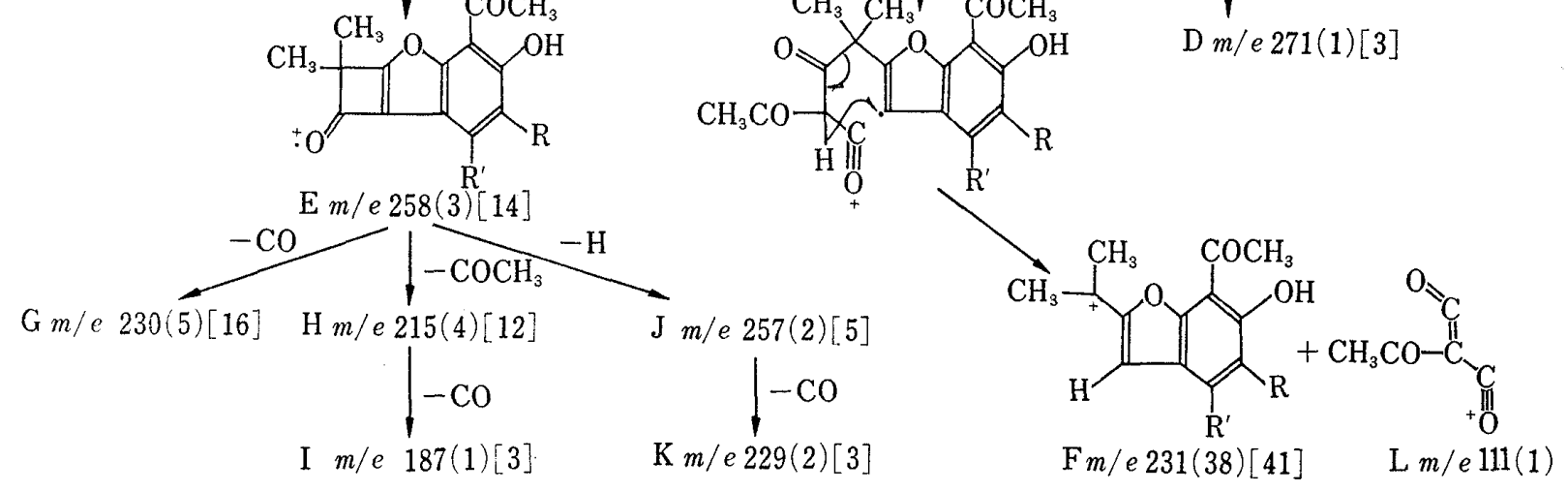

Chart 2. The Fragmentations of $\mathrm{V}\left(\mathrm{R}=\mathrm{CH}_{3}, \mathrm{R}^{\prime}=\mathrm{H}\right)$ and Isoanhydromethyldihydrousnic Acid Monoacetate $\left(\mathrm{R}=\mathrm{H}, \mathrm{R}^{\prime}=\mathrm{CH}_{3}\right)$

The figures in round and square brackets are the relative intensities of the fragment ions of the former and the latter, respectively.

9) T.A. Spencer, A.L. Hall and C. Fordham von Reyn, J. Org. Chem., 33, 3369 (1968). 


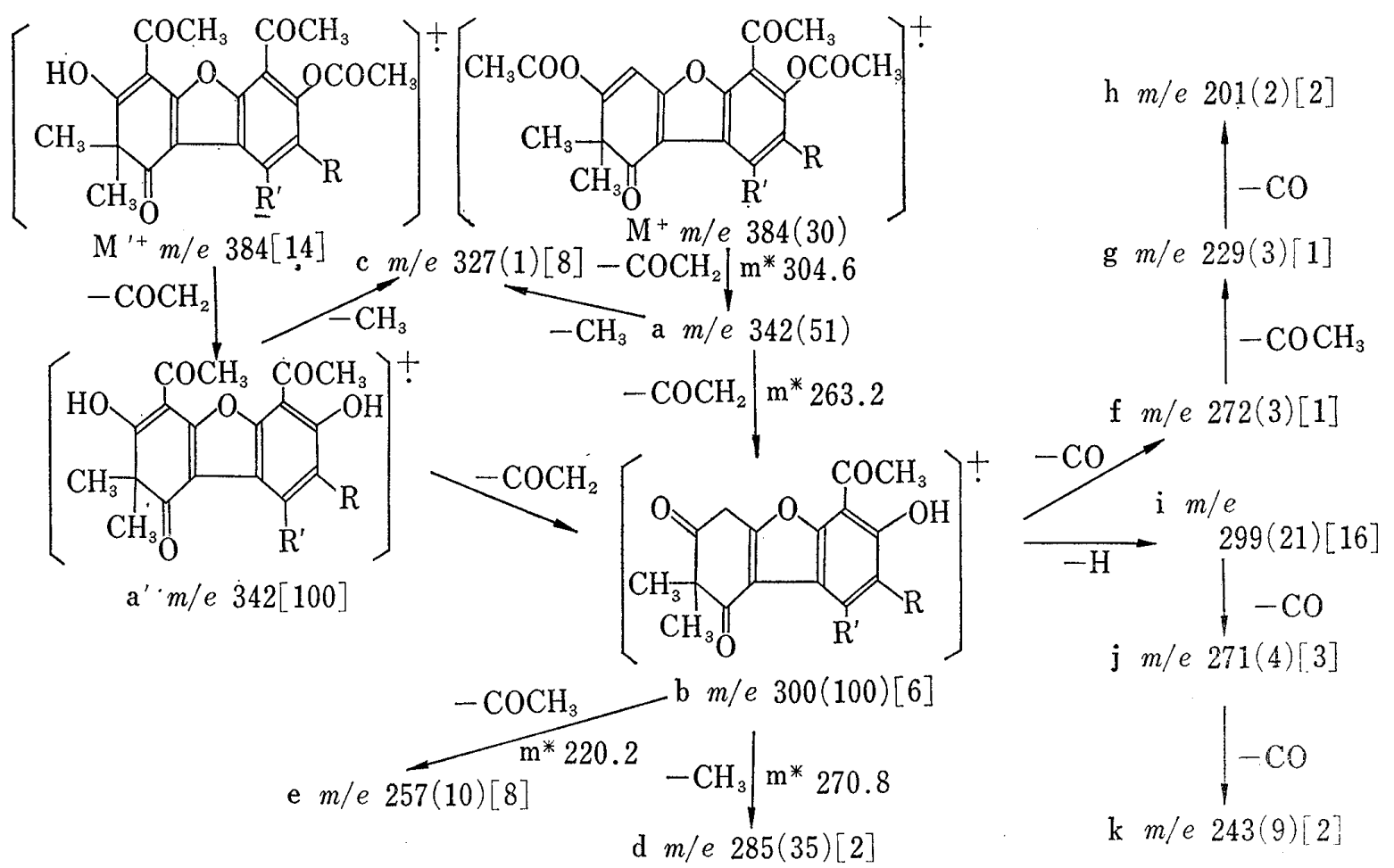

Chart 3. The Fragmentations of $\mathrm{X}\left(\mathrm{R}=\mathrm{CH}_{3}, \mathrm{R}^{\prime}=\mathrm{H}\right)$ and Anhydromethyldihydrousnic Acid Monoacetate $\left(\mathrm{R}=\mathrm{H}, \mathrm{R}^{\prime}=\mathrm{CH}_{3}\right)$

The figures in round and square brackets are the relative intensities of the fragment ions of the former and the latter, respectively. Typical broad peaks of metastable ions were observed in the spectrum of $\mathrm{X}$, but not in the spectrum of anhydromethyldihydrousnic acid monoacetate.

\section{TABLE IV}

\begin{tabular}{|c|c|c|c|c|c|c|c|}
\hline \multirow[b]{2}{*}{ Formula } & \multirow[b]{2}{*}{$\begin{array}{c}m / e \\
\text { (Calcd.) }\end{array}$} & \multicolumn{6}{|c|}{$m / e$ (Found) } \\
\hline & & Species & $\mathrm{V}$ & $\begin{array}{l}\text { Isoanhydro- } \\
\text { methyldihydro- } \\
\text { usnic acid } \\
\text { monoacetate }\end{array}$ & Species & $X$ & $\begin{array}{l}\text { Anhydro- } \\
\text { methyldihydro- } \\
\text { usnic acid } \\
\text { monoacetate }\end{array}$ \\
\hline $\mathrm{C}_{21} \mathrm{H}_{20} \mathrm{O}_{7}$ & 384.121 & $\mathrm{M}^{+}$ & 0.122 & 0.121 & $\mathrm{M}^{+}$ & 0.123 & 0.124 \\
\hline $\mathrm{C}_{19} \mathrm{H}_{18} \mathrm{O}_{6}$ & 342.110 & $\mathrm{~A}$ & 0.112 & 0.109 & $\mathrm{a}$ & 0.111 & 0.112 \\
\hline $\mathrm{C}_{18} \mathrm{H}_{15} \mathrm{O}_{6}$ & 327.087 & $B$ & 0.086 & 0.087 & $\mathrm{c}$ & 0.088 & 0.086 \\
\hline $\mathrm{C}_{17} \mathrm{H}_{16} \mathrm{O}_{5}$ & 300.100 & & & & $\mathrm{~b}$ & 0.100 & 0.099 \\
\hline $\mathrm{C}_{17} \mathrm{H}_{15} \mathrm{O}_{5}$ & 299.092 & C & 0.090 & 0.092 & $\mathrm{i}$ & 0.091 & 0.090 \\
\hline $\mathrm{C}_{16} \mathrm{H}_{13} \mathrm{O}_{5}$ & 285.076 & & & & $\mathrm{~d}$ & 0.079 & 0.076 \\
\hline $\mathrm{C}_{16} \mathrm{H}_{16} \mathrm{O}_{4}$ & 272.105 & & & & $\mathrm{f}$ & 0.105 & 0.104 \\
\hline $\mathrm{C}_{16} \mathrm{H}_{15} \mathrm{O}_{4}$ & . 271.097 & $\mathrm{D}$ & 0.095 & 0.102 & $\mathrm{j}$ & 0.095 & 0.098 \\
\hline $\mathrm{C}_{15} \mathrm{H}_{14} \mathrm{O}_{4}$ & 258.089 & $\mathrm{E}$ & 0.092 & 0.088 & & & \\
\hline $\mathrm{C}_{15} \mathrm{H}_{13} \mathrm{O}_{4}$ & 257.081 & $\mathrm{~J}$ & 0.081 & 0.081 & e & 0.083 & 0.083 \\
\hline $\mathrm{C}_{15} \mathrm{H}_{15} \mathrm{O}_{3}$ & 243.102 & & & & $\mathrm{k}$ & 0.106 & 0.103 \\
\hline $\mathrm{C}_{14} \mathrm{H}_{15} \mathrm{O}_{3}$ & 231.102 & $\mathrm{~F}$ & 0.102 & 0.103 & & & \\
\hline $\mathrm{C}_{14} \mathrm{H}_{14} \mathrm{O}_{3}$ & 230.094 & $\mathrm{G}$ & 0.095 & 0.095 & & & \\
\hline $\mathrm{C}_{14} \mathrm{H}_{13} \mathrm{O}_{3}$ & 229.086 & $\mathrm{~K}$ & 0.082 & 0.090 & $\mathrm{~g}$ & 0.086 & 0.083 \\
\hline $\mathrm{C}_{13} \mathrm{H}_{11} \mathrm{O}_{3}$ & 215.071 & $\mathrm{H}$ & 0.068 & 0.071 & & & \\
\hline $\mathrm{C}_{13} \mathrm{H}_{13} \mathrm{O}_{2}$ & 201.092 & & & & $\mathrm{~h}$ & 0.092 & 0.091 \\
\hline $\mathrm{C}_{12} \mathrm{H}_{11} \mathrm{O}_{2}$ & 187.076 & I & 0.074 & 0.074 & & & \\
\hline $\mathrm{C}_{5} \mathrm{H}_{3} \mathrm{O}_{3}$ & 111.008 & L & 0.007 & - & & & \\
\hline
\end{tabular}




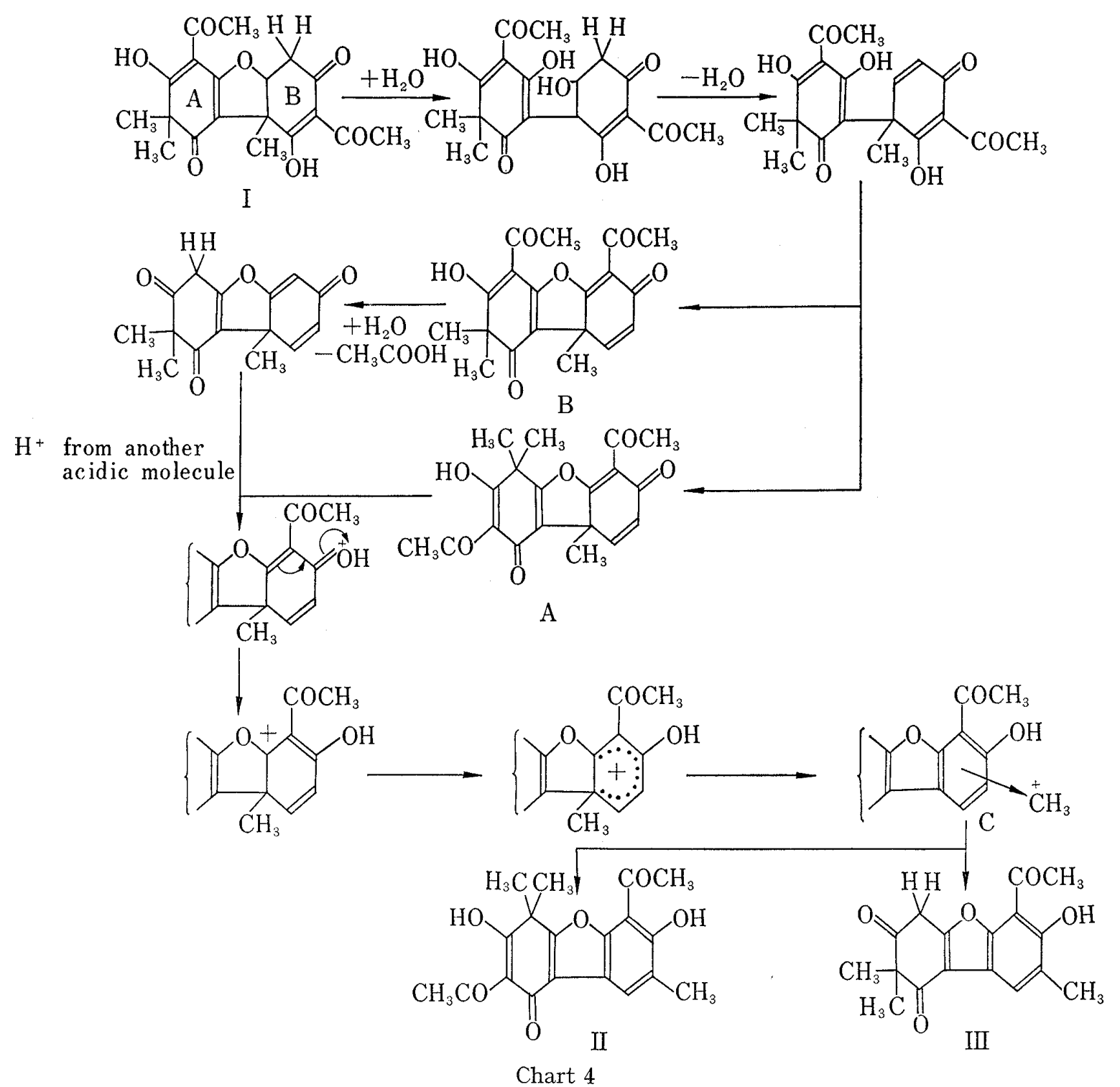

value) at $8.58\left(\mathrm{~s}, 6 \mathrm{H}\right.$, a gem-dimethyl), $7.72\left(\mathrm{~s}, 3 \mathrm{H}\right.$, aryl- $\left.\mathrm{CH}_{3}\right), 7.68(\mathrm{~s}, 3 \mathrm{H})$ and $7.64(\mathrm{~s}, 3 \mathrm{H})$ (two acetates), $7.24\left(\mathrm{~s}, 3 \mathrm{H}\right.$, aryl- $\left.\mathrm{COCH}_{3}\right), 3.13(\mathrm{~s}, 1 \mathrm{H},-\mathrm{CH}=\mathrm{C}<$ ) and $1.98(\mathrm{~s}, 1 \mathrm{H}$, aryl-H) in $\mathrm{CDCl}_{3}$ and the UV maxima $(\mathrm{m} \mu, \log \varepsilon)$ at $248.0(4.50), 281$ (3.82, sh) and $347(4.08)$. The presence of a signal at $3.13(1 \mathrm{H})$ and the absence of a signal at $5.96(2 \mathrm{H})$ indicate that $\mathrm{X}$ has an enol acetyl group. The alcoholysis product (XI) of $\mathrm{X}$ exhibits the IR bands $\left(\mathrm{cm}^{-1}\right)$ at 1750 (acetate), 1720 (six-membered ring $\mathrm{C}=\mathrm{O}), 1690\left(\right.$ aryl- $\left.\mathrm{COCH}_{3}\right), 1680(\alpha \beta$-unsatd. ring $\mathrm{C}=\mathrm{O})$, 1195 and $1070(-\mathrm{C}-\mathrm{O}-\mathrm{C}-)$ and the NMR signals ( $\tau$-value) at $8.55(\mathrm{~s}, 6 \mathrm{H}$, a gem-dimethyl), $7.72\left(\mathrm{~s}, 3 \mathrm{H}\right.$, aryl- $\left.\mathrm{CH}_{3}\right), 7.65\left(\mathrm{~s}, 3 \mathrm{H}\right.$, acetate), $7.28\left(\mathrm{~s}, 3 \mathrm{H}, \mathrm{COCH}_{3}\right), 5.95\left(\mathrm{~s}, 2 \mathrm{H},-\mathrm{CH}_{2}-\right)$ and $1.93(\mathrm{~s}, 1 \mathrm{H}$, aryl-H), indicating that the enol acetyl group of the ring $\mathrm{A}$ of $\mathrm{X}$ was eliminated to give XI by the alcoholysis and that XI exists in a diketoform as III. These chemical and spectral data indicate that $\mathrm{X}$ is a normal type of compound as anhydromethyldihydrousnic acid $^{6)}$ and III, $\mathrm{X}$ and XI could be formulated as shown in chart 1.

Mass spectral analysis. ${ }^{10}$ ) Analyses of peaks of the spectra of $\mathrm{V}$ and isoanhydromethyldihydrousnic acid monoacetate (isotypes of compound) (Chart 2) and those of X and anhydromethyldihydrousnic acid monoacetate (normal types of compound) (Chart 3) were carried out in millimass order (Table IV). Some of the fragmentations and the structures of the fragment-

10) Cf. H. Budzikiewicz, C. Djerassi and D.H. William, "Interpretation of Mass Spectra of Organic Compound," Holden-Day Inc. Sanfrancisco, 1964. 
ions of these compounds could be assumed as shown in Chart 2 and 3 . The fragmentations of species $m / e 342$ (A) to species m/e 258 (E) by path (i) and species $m / e 231$ (F) by path (ii) might be characteristic of the isotypes of compound.

The reaction mechanism of the formation of II and III from methyldihydrousnic acid (I) could tentatively be postulated as shown in Chart 4 . Namely, the first stage of this reaction is the fission of $-\mathrm{C}-\mathrm{O}-\mathrm{C}-$ bond in the furan ring with production of two hydroxyl groups, of which the $\mathrm{OH}$ group in the ring $\mathrm{B}$ is then dehydrated to produce a double bond. At the next stage, the $\mathrm{OH}$ group in the ring $\mathrm{A}$ and the enol $\mathrm{OH}$ group in the ring $\mathrm{B}$ combine with each other to give $-\mathrm{C}-\mathrm{O}-\mathrm{C}-$ bond in two ways, giving two compounds $\mathrm{A}$ and $\mathrm{B}$. A might give II and $\mathrm{B}$, after the hydrolytic fission of $\mathrm{COCH}_{3}$ group in the ring $\mathrm{A}$, might give III through $\pi$-complex intermediate $\mathrm{C}$ by the Jacobson rearrangement. ${ }^{11)}$ In this case, the effect of the meta-directing group $\left(\mathrm{COCH}_{3}\right)$ and of the ortho-directing group $(\mathrm{OH})$ would be considered to cause the 1,3migration of the angular methyl group, but further investigation on this point should be performed (Chart 4).

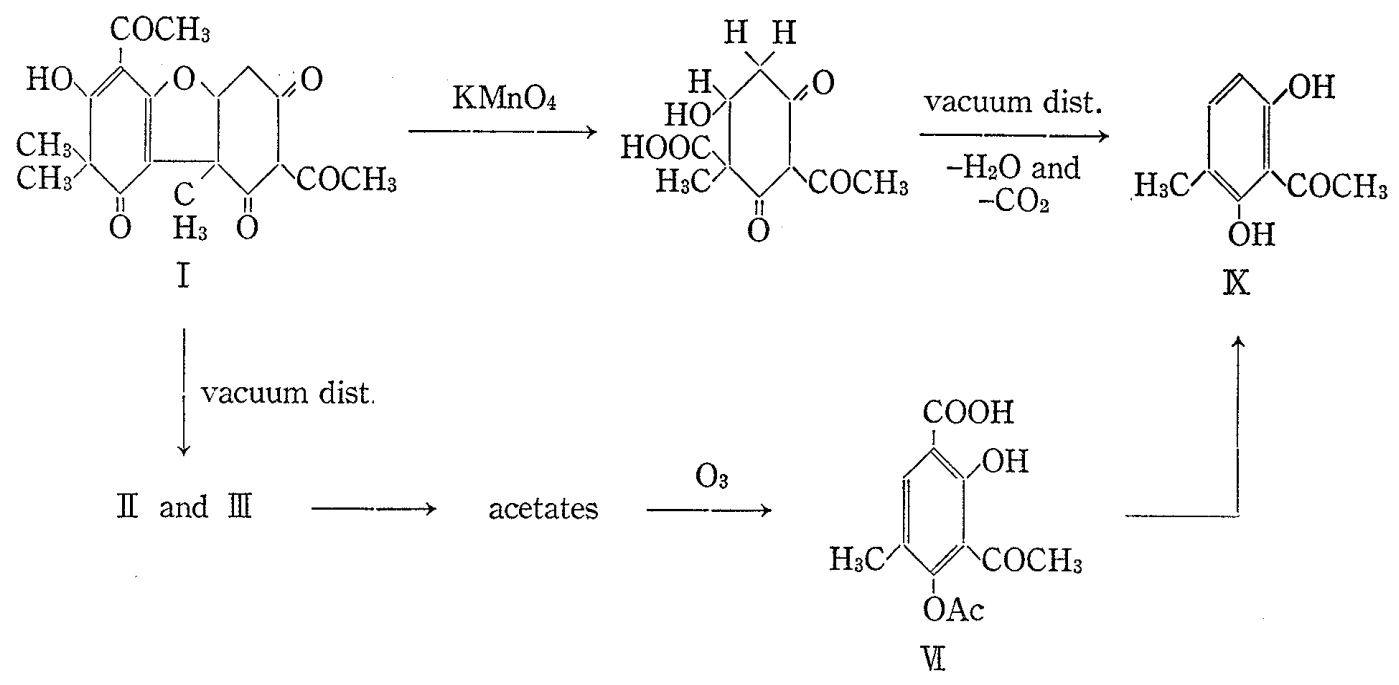

Chart 5

It is of interst to assume that methyldihydrousnic acid (I) gives 3-methyl-2,6-dihydroxyacetophenone (IX) either by the potassium permanganate oxidation, followed by the vacuum distillation ${ }^{5}$ or by the vacuum distillation, followed by the ozone oxidation as shown in Chart 5 .

\section{Experimental}

The IR spectra were measured in $\mathrm{KBr}$ pellet by Nippon Bunko DS-402G spectrometer, the UV spectra in EtOH by Hitachi EPS-2U recording spectrometer, the NMR spectra in $\mathrm{CDCl}_{3}$ by JNM-C-60-H high resolution NMR instrument at $60 \mathrm{Mc}$ with $\left(\mathrm{CH}_{3}\right)_{4} \mathrm{Si}$ as internal reference and the mass spectra by JMS-01SG mass spectrometer, the ionizing current kept at $200 \mu \mathrm{A}$, while the ionizing energy being maintained at $75 \mathrm{eV}$, not otherwise stated.

Dry-Distillation of Methyldihydrousnic Acid (I) — Three grams of I was heated at $220-240^{\circ}$ for $30 \mathrm{~min}$. After removing acetylacetone (a rose coloration with 0 -phenylenediamine) and acetic acid, the residue was distilled in vacuo under $1 \mathrm{mmHg}$ pressure to give reddish yellow distillate, which solidified by treatment with methanol. The yellow substance was recrystallised from benzene to give faint yellow crystal of $\mathrm{mp}$ $243^{\circ}$. Yield: $100 \mathrm{mg}$. $\mathrm{FeCl}_{3}$ reaction: violet-brown. $R f: 0.25$ (benzene: AcOEt=4:1, Kieselgel G). Anal. Calcd. for $\mathrm{C}_{19} \mathrm{H}_{18} \mathrm{O}_{6}: \mathrm{C}, 66.66 ; \mathrm{H}, 5.30$. Found: $\mathrm{C}, 66.84 ; \mathrm{H}, 5.47$. From the mother liquor, yellow needle

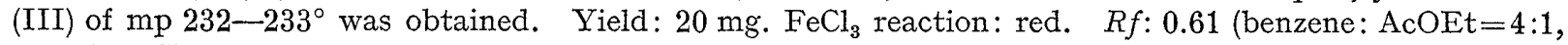
Kieselgel G). Anal. Calcd. for $\mathrm{C}_{17} \mathrm{H}_{16} \mathrm{O}_{5}: \mathrm{C}, 67.99 ; \mathrm{H}, 5.37$. Found: $\mathrm{C}, 67.95 ; \mathrm{H}, 5.40$.

11) P. de Mayo, "Molecular Rearrangements," Part I, p. 299. 
Dry-Distillation of I with $\mathrm{CaCl}_{2}-\mathrm{I}(1.5 \mathrm{~g})$ was mixed with $\mathrm{CaCl}_{2}(1.5 \mathrm{~g})$ and heated at $200^{\circ}$ for $20 \mathrm{~min}$. The residue was then distilled under $1 \mathrm{mmHg}$ pressure to give yellow distillate which solidified by treatment with methanol. The yellow substance was chromatographed on Kieselgel $\mathrm{H}(30 \mathrm{~g})$ with benzene-AcOEt $(9: 1)$ as eluent. The first yellow eluate gave crystal of $\mathrm{mp} 230^{\circ}$, which was proved to be identical with III by the mixed fusion and IR spectra. The second yellow eluate gave crystal of mp $240-241^{\circ}$, which was proved to be identical with II by the mixed fusion and IR spectra. Anal. Calcd. for $\mathrm{C}_{19} \mathrm{H}_{18} \mathrm{O}_{6}: \mathrm{C}_{2}, 66.66$; $\mathrm{H}, 5.30$. Found: $\mathrm{C}, 66.69 ; \mathrm{H}, 5.31$.

Acetylation of II-A mixture of $0.37 \mathrm{~g}$ of II, $0.37 \mathrm{~g}$ of sodium acetate and $6 \mathrm{ml}$ of acetic anhydride was heated on an oil bath at $160^{\circ}$ for $1.5 \mathrm{hr}$. After cooling, the mixture was poured into ice water to give precipitate, which was crystallised from EtOH to give $\mathrm{V}$ of $\mathrm{mp} 128^{\circ}$ as colorless plate. Yield: $140 \mathrm{mg}$. $\mathrm{FeCl}_{3}$ reaction: red. Rf: 0.35 (benzene: AcOEt $=4: 1$, Kiesegel G). Anal. Calcd. for $\mathrm{C}_{21} \mathrm{H}_{20} \mathrm{O}_{7}: \mathrm{C}_{2} 65.61$; $\mathrm{H}, 5.24$. Found: $\mathrm{C}, 65.47 ; \mathrm{H}, 5.57$.

Acetylation of III-A mixture of $0.5 \mathrm{~g}$ of III, $0.5 \mathrm{~g}$ of sodium acetate and $6 \mathrm{ml}$ of acetic anhydride was warmed on a water bath for $1.5 \mathrm{hr}$. After cooling, the mixture was poured into ice water and the mixture was allowed to stand overnight. Precipitate was crystallised from EtOH to give $\mathrm{X}$ of $\mathrm{mp} 165-166^{\circ}$ as faint yellow needles. Yield: $50 \mathrm{mg}$. $R f: 0.68$ (benzene:AcOEt $=4: 1$, Kieselgel G). Anal. Calcd. for $\mathrm{C}_{21} \mathrm{H}_{20} \mathrm{O}_{7}: \mathrm{C}, 65.61 ; \mathrm{H}, 5.24$. Found: $\mathrm{C}, 65.55 ; \mathrm{H}, 5.30$.

Acetylation of the Dry-Distillate of $\mathrm{I}$-A mixture of the yellow distillate $(3.8 \mathrm{~g})$, obtained from I mentioned above, $38 \mathrm{ml}$ of acetic anhydride and 6 drops of conc. $\mathrm{H}_{2} \mathrm{SO}_{4}$ was warmed on a water bath for $1.5 \mathrm{hr}$. After cooling, the mixture was poured into water to give brown precipitate, which was crystallised from EtOH to give crystal of $\mathrm{mp} 165-166^{\circ}$ which was proved to be identical with $\mathrm{X}$ by the mixed fusion and IR spectra. Yield: 0.7 g. Anal. Calcd. for $\mathrm{C}_{21} \mathrm{H}_{20} \mathrm{O}_{7}: \mathrm{C}, 65.61 ; \mathrm{H}, 5.24$. Found: C, 65.64; $\mathrm{H}, 5.34$. From the mother liquor, crystal of $\mathrm{mp} 128^{\circ}$ was obtained, which was proved to be identical with $\mathrm{V}$ by the mixed fusion and IR spectra. Yield: $0.15 \mathrm{~g}$. Anal. Calcd. for $\mathrm{C}_{21} \mathrm{H}_{20} \mathrm{O}_{7}: \mathrm{C}, 65.61 ; \mathrm{H}, 5.24$. Found: C, $65.38 ; \mathrm{H}, 5.16$.

Deacetylation of $\mathbf{V}$ to $\mathrm{II}-\mathrm{V}(97 \mathrm{mg})$ was dissolved in ice-cold conc. $\mathrm{H}_{2} \mathrm{SO}_{4}(0.5 \mathrm{ml})$ and the solution was kept in cold for $20 \mathrm{~min}$ and poured into ice water to give crystal of $\mathrm{mp} 241-242^{\circ}$ (from benzene), which was proved to be identical with II by the mixed fusion and IR spectra. Yield: $50 \mathrm{mg}$. Anal. Calcd. for $\mathrm{C}_{19} \mathrm{H}_{18} \mathrm{O}_{6}: \mathrm{C}, 66.66 ; \mathrm{H}, 5.30$. Found: $\mathrm{C}, 66.52 ; \mathrm{H}, 5.30$.

Deacetylation of $\mathbf{X}$ to $\mathbf{I I I}-\mathrm{X}(100 \mathrm{mg})$ was dissolved in ice-cold conc. $\mathrm{H}_{2} \mathrm{SO}_{4}(1 \mathrm{ml})$ and the solution was allowed to stand in cold for $20 \mathrm{~min}$ and poured into ice water to give III of $\mathrm{mp} 233^{\circ}$. Anal. Calcd. for $\mathrm{C}_{17} \mathrm{H}_{16} \mathrm{O}_{5}: \mathrm{C}, 67.99 ; \mathrm{H}, 5.37$. Found: $\mathrm{C}, 67.66 ; \mathrm{H}, 5.31$.

Oximation of II-A mixture of II $(200 \mathrm{mg})$ in EtOH and hydroxylamine hydrochloride $(600 \mathrm{mg})$ and sodium acetate $(600 \mathrm{mg})$ in water was warmed on a water bath for $5 \mathrm{hr}$ and worked up as usual to give colorless crystal of mp $287^{\circ}$ (decomp.) (IV) from EtOH. Anal. Calcd. for $\mathrm{C}_{19} \mathrm{H}_{18} \mathrm{O}_{5} \mathrm{~N}_{2}:$ C, 64.40; $\mathrm{H}, 5.12$; $\mathrm{N}, 7.91$. Found: $\mathrm{C}, 64.32 ; \mathrm{H}, 5.32 ; \mathrm{N}, 7.39$. IR $v_{\max }\left(\mathrm{cm}^{-1}\right): 1665,1601,1545,1495,1400,1297,1140$, $1025,968,888$.

Ozonolysis of $\mathrm{V}-\mathrm{V}(700 \mathrm{mg})$ was dissolved in $\mathrm{CHCl}_{3}(15 \mathrm{ml})$ and ozonized oxygen was passed through for $2 \mathrm{hr}$ under ice cooling. The $\mathrm{CHCl}_{3}$ solution was then distilled off in vacuo and water $(15 \mathrm{ml})$ was added to the residue and the solution was warmed on a water bath at $45^{\circ}$ for 30 min and allowed to stand at room temperature for 2 days. The oxidation product was extracted with ether five times and after drying with anhyd. $\mathrm{Na}_{2} \mathrm{SO}_{4}$, ether was distilled off to give colorless needle (VI) of $\mathrm{mp} 170-172^{\circ}$ from benzene. Yield: $17 \mathrm{mg}$. $\mathrm{FeCl}_{3}$ reaction:violet. $R f: 0.33$ (benzene: dioxane: AcOH=90:25:4, Kieselgel G). UV $\lambda_{\max }(\mathrm{m} \mu$, $(\log \varepsilon)): 223(4.31), 321(3.75)$. Anal. Calcd. for $\mathrm{C}_{12} \mathrm{H}_{12} \mathrm{O}_{6}: \mathrm{C}, 57.14 ; \mathrm{H}, 4.80$. Found: C, 57.32; $\mathrm{H}, 4.79$.

Methylation of VI-One-tenth gram of VI in ether $(20 \mathrm{ml})$ was methylated with diazomethane to give colorless plate (VII) of $\mathrm{mp} 123-125^{\circ}$ from methanol. $\mathrm{FeCl}_{3}$ reaction:violet. $R f$ : 0.69 (benzene: AcOEt $=4: 1$, Kieselgel G). UV $\lambda_{\max }(\mathrm{m} \mu,(\log \varepsilon)): 223.2$ (4.45), 251.6 (3.89, shoulder), 320 (3.91). Anal. Calcd. for $\mathrm{C}_{13} \mathrm{H}_{14} \mathrm{O}_{6}: \mathrm{C}, 58.64 ; \mathrm{H}, 5.30$. Found: $\mathrm{C}, 58.74 ; \mathrm{H}, 5.39$.

Deacetylation of VII__ VII $(42 \mathrm{mg})$ was dissolved in ice-cold conc, $\mathrm{H}_{2} \mathrm{SO}_{4}(0.8 \mathrm{ml})$ and the mixture was treated as mentioned above to give crystal (VIII) of $\mathrm{mp} 102-103^{\circ}$ from methanol. $\mathrm{FeCl}_{3}$ reaction:violet. UV $\lambda_{\max }(\mathrm{m} \mu,(\log \varepsilon)): 236.4$ (4.45), 263.7 (4.33), 281 (4.22, shoulder), 341 (3.70). IR $v_{\max }\left(\mathrm{cm}^{-1}\right): 1670$ (chelated $\mathrm{COOCH}_{3}$ ), 1628 (chelated $\mathrm{COCH}_{3}$ ). Anal. Calcd. for $\mathrm{C}_{11} \mathrm{H}_{12} \mathrm{O}_{5}: \mathrm{C}, 58.92 ; \mathrm{H}, 5.40$. Found: C, 58.88; $\mathrm{H}, 5.43$.

Hydrolysis, followed by Decarboxylation of VI_-VI (90 mg) was warmed in $10 \%$ alcoholic $\mathrm{KOH}$ $(15 \mathrm{ml})$ on a water bath for $1 \mathrm{hr}$ and the solution was evaporated in vacuo and $3 \mathrm{ml}$ of water was added. After acidification with dil. $\mathrm{HCl}$, the resulting yellow precipitate was heated at $210^{\circ}$. Decarboxylation took place under bubbling. After the end of bubbling, the product was sublimated at $120^{\circ}$ under $1 \mathrm{mmHg}$ pressure to give crystal (IX) of $\mathrm{mp} 134-136^{\circ}$, which was proved to be identical with 3-methyl 2,6-dihydroxy acetophenone ${ }^{5}$ ) by the mixed fusion and UV, IR spectra. $\mathrm{FeCl}_{3}$ reaction: blue-green. $\mathrm{UV} \lambda_{\max }(\mathrm{m} \mu,(\log \varepsilon))$ : 224.5 (4.00), 273 (4.01), 352 (3.45). Anal. Calcd. for $\mathrm{C}_{9} \mathrm{H}_{10} \mathrm{O}_{3}: \mathrm{C}, 65.05 ; \mathrm{H}, 6.07$. Found: C, 65.11; $\mathrm{H}, 6.09$.

Ozonolysis of $\mathrm{X}-\mathrm{X}(1.2 \mathrm{~g})$ was dissolved in $\mathrm{CHCl}_{3}(30 \mathrm{ml})$ and ozonised oxygen was passed through for $2.5 \mathrm{hr}$ under ice cooling and the $\mathrm{CHCl}_{3}$ solution was treated as mentioned above to give colorless needle 
of $\mathrm{mp} 170-172^{\circ}$ from benzene, which was proved to be identical with VI by the mixed fusion, UV and IR spectra. Anal. Calcd. for $\mathrm{C}_{12} \mathrm{H}_{12} \mathrm{O}_{6}: \mathrm{C}, 57.14 ; \mathrm{H}, 4.80$. Found: C, 57.05; $\mathrm{H}, 4.71$.

Alcoholysis of $\mathrm{X}-\mathrm{X}(0.3 \mathrm{~g})$ in EtOH or $\mathrm{MeOH}(20 \mathrm{ml})$ was boiled on a water bath for $45 \mathrm{hr}$. The solution gave yellow crystal $(0.2 \mathrm{~g})$ after cooling, which was crystallised from EtOH to give crystal (XI) of $\mathrm{mp} 218-219^{\circ}$. UV $\lambda_{\max }(\mathrm{m} \mu,(\log \varepsilon)): 249.5(4.40), 257.2$ (4.42), 281 (3.87, shoulder), 307 (3.44, shoulder). Anal. Calcd. for $\mathrm{C}_{19} \mathrm{H}_{18} \mathrm{O}_{6}: \mathrm{C}, 66.66 ; \mathrm{H}, 5.30$. Found: $\mathrm{C}, 66.18 ; \mathrm{H}, 5.41$. Mass Spectrum $(m / e$, relative intensity): $M+342(3), 300(100), 299(2), 285(2), 272(18), 271(1), 257(10), 244(15), 230(80), 229(5)$, $202(39), 201(5)$ and $187(17) . \quad(200 \mu \mathrm{A}, 30 \mathrm{eV}$. electrical detection).

Acknowledgement The authors express their gratitude to Dr. Y. Asahina, Emeritus Professor of University of Tokyo, for his encouragement throughout this study. Thanks are due to prof. T. Fujii of this faculty for discussing the reaction mechanism and Mrs. S. Sasaki (née Yamada) for her technical assistance at early stage of this study and Miss. S. Kitagawa of this faculty for measuring mass spectra and Mr. Y. Itatani of this faculty for measuring NMR spectra and for elemental analyses. 